\title{
Synthesis and Characterization of Chitosan-Silica Membranes for Treating Hotel Wastewater Treatment as Affected by Mass of Poly Ethylene Glycol and Poly Vinyl Alcohol
}

\author{
Jhon Armedi Pinem ${ }^{1, *}$, Dessy Natalia Indah Panjaitan ${ }^{1}$, Muhammad Rifai Siregar ${ }^{1}$, \\ Syamsu Herman ${ }^{1}$, Edy Saputra ${ }^{2, *}$ (1) \\ ${ }^{1}$ Separation and Purification Laboratory, Department of Chemical Engineering Universitas Riau, Pekanbaru 28293, Indonesia. \\ ${ }^{2}$ Chemical Reaction Engineering Laboratory, Department of Chemical Engineering Universitas Riau, Pekanbaru 28293,
}

\begin{abstract}
Chitosan-silica composite membrane was an attractive choice for the purification process because their porous size and morphology provide higher selectivity. In this study, the synthesis and characterization of chitosan-silica membranes were carried out with a mass variation of Poly Ethylene Glycol (PEG): 0.5, 2.5, 5 g, Poly Vinyl Alcohol (PVA): 1, 2, 3 g; and pressure 1, 2, 3 bar for the hotel wastewater treatment. The purpose of this study was to determine the characteristics of chitosan-silica membranes obtained by SEM and mechanical characteristic of the membrane, and to study the effect of membrane composition to performance of the chitosan-silica membrane obtained. The SEM test results showed a relatively small pore size of PEG $0.5 \mathrm{~g}(0.061 \mu \mathrm{m})$ and PVA $2 \mathrm{~g}(0.0284 \mu \mathrm{m})$. Tensile strength analysis showed that membrane with the highest tensile strength was 19.14 MPa for PEG and 13.7 MPa for PVA. The most effectve performance of membrane showed by the composition of $2.5 \mathrm{~g}$ of PEG with the flux $18.19 \mathrm{~L} / \mathrm{m}^{2} . \mathrm{h}$ and rejection of BOD (50.76\%), COD (46.09\%) and TSS (48\%). On the other hand, $3 \mathrm{~g}$ of PVA membrane composition was the most effective with the flux $20.13 \mathrm{~L} / \mathrm{m}^{2} . \mathrm{h}$ and rejection of BOD (62.84\%), COD (64.73\%) and TSS (38.40\%). The characteristics of permeability, selectivity, and membrane pore statistics show that the silica membrane is an ultrafiltration membrane.
\end{abstract}

Key words: chitosan, flux, membrane, rejection, silica, wastewater.

\section{INTRODUCTION}

Hotels wastewater is produced from hotel activities and disposed of in the environment. The Regulation of Ministry of The Environment Number 68 of 2016 states that it is necessary to process any waste prior to disposal. Most hotel wastewater managements employ Extended Aeration system, also called the Sewage Treatment Plant. This system treats waste through physical, chemical and biological processes before being discharged into the environment. The drawback of this system, however, is that the processed parameters have not met the quality standards [1].

One alternative to overcome the drawback is the application of separation technology through the process of coagulation, flocculation and ultrafiltration membranes. This membrane technology is advantageous in that it requires low amount of energy and relatively small area. It does not produce contaminants or pollutants and manages to conduct separation swiftly. The feasible materials to use for the membrane are chitosan and silica [2]. Chitosan membranes are hydrophilic, non toxic, biodegradable, reactive to metal ions, and has large surface area. The inorganic compounds are primarily composed of silica that increases the stability of chitosan membranes through the cross-link formation with silica, which is made possible by the creation of hydrogen bonds between chitosan structures and silica. The addition of silica to chitosan solution will also make the membrane porogene that the flux of permeate and its permeability boost [3].
Arthanareeswaran (2010) conducted a study on the preparation, characterization and the performance of ultrafiltration membranes with polymer (additives). The results of their study showed that the addition of $2.5 \%$ PEG resulted in the average membrane pore size of $38.9 \AA$, and the addition of $7.5 \%$ PEG contributed to the average pore size of 48.7 Á.

Á. In relation to this, [5] studied the effect of PEG additives on the morphology and performance of polysulfone ultrafiltration membranes. The study concluded that the more PEG was used, the higher the number of pores and the resulting flux. Another related study by [6] investigated the dehydration of pervaporation of ethylene glycol with chitosan-PVA membranes. The produced membranes are mechanically strong and not brittle. Lastly, [7] characterized the performance of silica membranes from rice husk to determine the effect of PVA addition. The experiment produced a membrane with a denser pore size. This study aims to determine the effect of the PEG and PVA composition on the characteristics of chitosan-silica membrane and operating pressure on membrane performance.

$\begin{array}{ll}\text { Received } & \text { : July 27, 2019 } \\ \text { Revised } & \text { : August 13, 2019 } \\ \text { Accepted } & \text { : August 16, 2019 }\end{array}$




\section{EXPERIMENT}

Materials: chitosan $(250 \mathrm{~g})$ was purchased from CV Chimultiguna (Indramayu, Indonesia). Sodium hydroxide $(98 \%, 100 \mathrm{~g})$, acetic acid $(98 \%, 100 \mathrm{~mL})$ and aquades for all experiments were obtained from Chemical Engineering Laboratory, Universitas Riau (Indonesia). Chemicals such as pure silica (1000 g), Poly Ethylene Glycol 400 (PEG-400, $1000 \mathrm{~mL}$ ) and Poly Vinyl Alcohol (PVA) (1000 g) werebought from Bratachem (Pekanbaru, Indonesia); aluminum sulfate $(50 \mathrm{~g})$ and calcium hydroxide $(50 \mathrm{~g})$ were from Sari Laborta (Pekanbaru, Indonesia); and hotels wastewater was from one of the four star hotels in Pekanbaru (Indonesia).

Membrane Preparation: Membrane films were synthesized using the phase inversion method, that is, evaporating solvents at a drying temperature of $70^{\circ} \mathrm{C}[8] . \mathrm{A}$ total of $20 \mathrm{~mL}$ of chitosan solution was put into Erlenmeyer, added with $20 \mathrm{~mL}$ of silica solution and stirred with a magnetic stirrer under $70^{\circ} \mathrm{C}$ with the stirring speed of 250 rpm for 30 minutes. After the solution became homogeneous, about $20 \mathrm{~mL}$ of PVA 1; 2; $3 \mathrm{~g}$ and PEG 0.5; 2.5; $5 \mathrm{~g}$ were added into it. The casting solution was stirred for the second time until homogeneous, printed in a petri dish and left for 48 hour (under $25^{\circ} \mathrm{C}$ ) until the membrane was dry. The mold was steeped using $1 \% \mathrm{NaOH}$ solution to remove the membrane. The membrane was then cut into circle with a diameter of $\pm 5 \mathrm{~cm}$.

The hotel wastewater was put into the refrigerator for 12 hour. Prior to main experiment, the waste sample was treated with a coagulation-flocculation process, before which it was analyzed using BOD, COD, and TSS parameters [9]. The analysis was conducted at the Material Testing Unit of the Public Works and Spatial Planning Laboratory in Riau.

Separation Process Using Membrane: The membrane made in the first process was then tested using what is called the Dead-End system of an ultrafiltration cell (with pressure ranging from 1-5 bar). The membrane to be tested was cut into circle with a diameter of $\pm 5 \mathrm{~cm}$ and placed on the base of the equipment. The hotel liquid waste as the sample water was put into a feed tube of $\pm 150 \mathrm{~mL}$. in the filtration cell the operating pressure is given with variation of 1,2 and 3 bar so that the sample water flew through the membrane called permeate. Afterwards, the exit permeate was collected and the volume of which was measured. The schematic diag of the ultrafiltration process can be seen in Figure 1 .

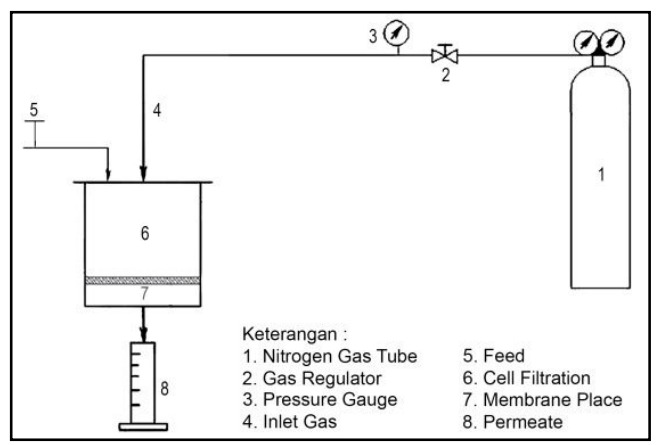

Fig. 1. Schematic Diagram of the Ultrafiltration Process
Membrane characterization: The membrane went through a series of tests including morphological, tensile and FTIR test.

\section{a. Membrane Morphology}

The statistic of membrane pore can be analyzed by scanning electron microscope. The scanning by SEM was carried out on the top surface of the membrane to identify the formed membrane pore, and the SEM testing was conducted at Universitas Diponegoro using SEM tool.

b. Mechanical Properties of Membranes

A quality membrane is a membrane with good mechanical properties. In this study, measurements of the membranes' mechanical properties were done using a texture analyzer tool. From the results of the tensile test, the modulus young value can be determined. The tensile test procedure is that the membrane was pulled at a speed of 5 $\mathrm{mm} / \mathrm{s}$ until it breaks. After that, the values of stress, strain and modulus young were obtained [10].

c. Fourier Transform Infrared (FTIR)

Observations on functional groups were carried out using FTIR IRPrestige-21. This test aims to confirm and study the composition of chitosan-silica used in the manufacture of membranes to the membrane structure. The FTIR membrane spectrum was collected at the FMIPA Laboratory of Universitas Riau at a wavelength of 4500-600 $\mathrm{cm}^{-1}$.

Membrane Performance: The performance test against the flux value and rejection of BOD, COD and TSS of the hotel wastewater. BOD (Biochemical Oxygen Demand) was a measurement parameter for the amount of oxygen needed by bacteria to break down almost all organic substances that are dissolved and suspended in wastewater. COD (Chemical Oxygen Demand) was the amount of oxygen needed to oxidize organic substances contained in wastewater. TSS was Total Suspended Solid which exceeds quality standards. The permeate collected in the separation process using membranes was used to calculate the flux value. The water flux, Jw in each experiment was calculated based on the time $t$ (hour) required to collect the permeate with the following equation:

$$
J w=\frac{1}{A} \frac{\Delta V}{\Delta t}
$$

A = effective surface area of the membrane $\left(\mathrm{m}^{2}\right)$

$\mathrm{V} \quad$ = volume of collected permeate $(\mathrm{mL})$

The flux graph against the pressure is plotted and the resulted slope is the permeability of the membrane [11]. The calculation of the rejection value at operating pressure $1,2,3$ bar was done by analyzing the concentration of each permeate and feed. Membrane rejection values can be determined using the following equations:

$$
\% R=\left(1-\frac{c p}{c f}\right) \times 100
$$

$\mathrm{Cp}=$ permeat concentration $(\mathrm{ppm})$

$\mathrm{Cf}=$ feed concentration $(\mathrm{ppm})$ 

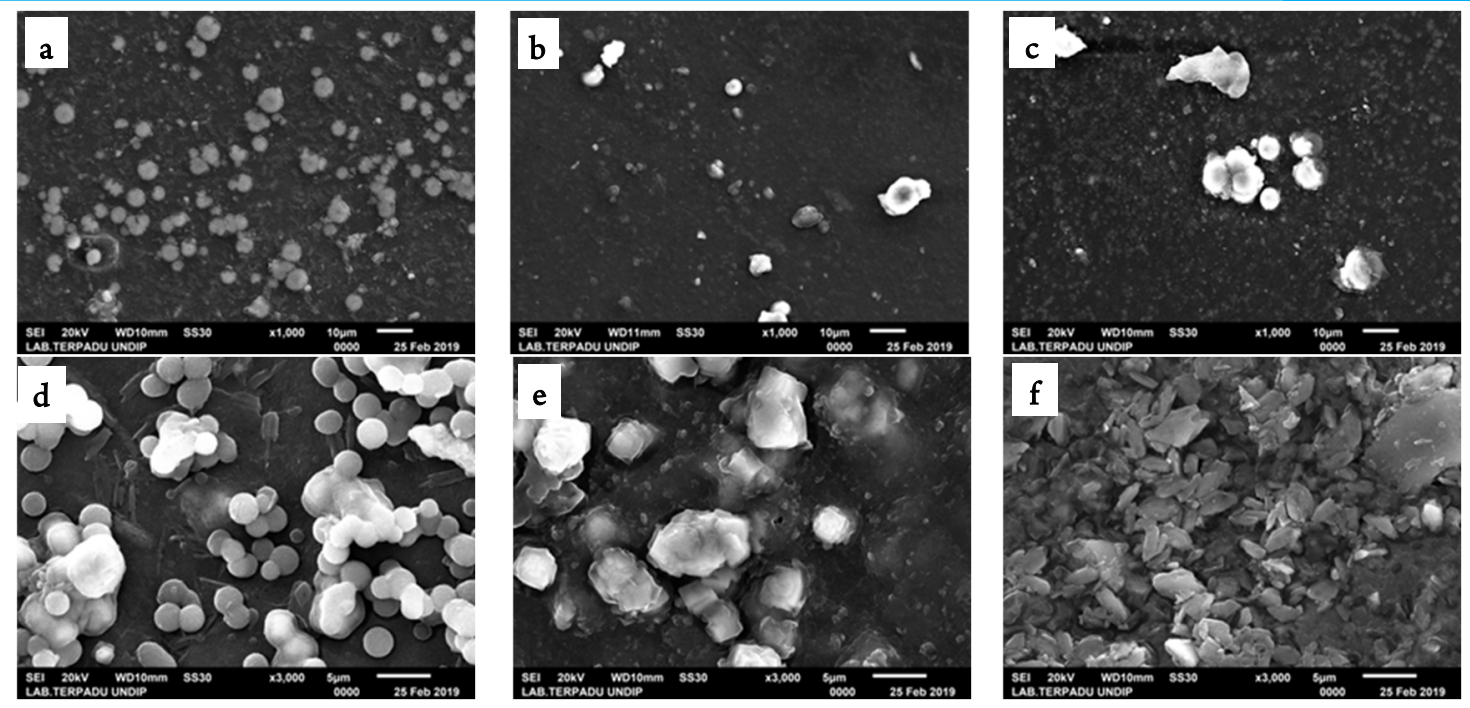

Fig. 2. Upper Surface Membrane (a) Composition PEG 0.5 g (b) Composition PEG 2.5 g (c) Composition PEG 5 g (d) Composition PVA $1 \mathrm{~g}$ (e) Composition PVA $2 \mathrm{~g}$ (f) Composition PVA $3 \mathrm{~g}$

\section{RESULTS AND DISCUSSION}

3.1 The Effect of PEG and PVA Composition on Membrane Morphology

Scanning Electron Microscopy (SEM) is useful to investigate the morphological structure of the membrane. In Figures 2 (a), (b), (c) it is visible that the surface of the chitosan-silica membrane is rough and non-homogeneous, and there are clumps and basins due to the less homogeneous composite solution and the addition of silica to the membrane. The addition of silica to chitosan membrane material functions as porogen and forms a gap in the membrane. The solution is less homogeneous because when the casting solution mold is left open, the solvent in the upper layer of the membrane diffuses into the atmosphere made the top layer lacks solvent [12].

The membrane with a mass of $3 \mathrm{~g}$ PVA has a smaller pore size (diameter) on average compared to that of PVA 1 $\mathrm{g}$ and PVA $2 \mathrm{~g}(0.0284 \mu \mathrm{m}$ with a surface area of 0.00196 $\mu \mathrm{m})$. This shows that the produced chitosan-silica membrane is an ultrafiltration membrane with a pore range between $0.001 \mu \mathrm{m}-0.1 \mu \mathrm{m}$ [11]. More PVA mass results in tighter membrane's top layer and smaller pore size. The formed of pore is influenced by the concentration of polymer composing the membrane. In this study, some chitosan powders could not dissolve completely and thus dried in the membrane, which is indicated by a white circle on the Figure 2 (a), (b), (c). [7] characterized the performance of silica membranes from rice husk to determine the effect of added 1-5 $\mathrm{g}$ of PVA. The form of the pores were found $30 \%$ more denser on account of the concentration of the membrane polymer. The finding was the same with the result of this study that when the amount of chitosan outnumbers that of PVA, the pores on the membrane are tighter and smaller.

The PEG composition has an influence on the membrane pores produced, where the greater the PEG mass used in the membrane making process, the diameter of pore formed was even greater. Figure 2 (d), (e), (f) show that the more composition of PEG used in the membrane, the pores on the membrane will be more evenly distributed that leads to greater pores. The reasons fot this is that as an additive, PEG is more a pore-forming agent than a pore reducing agent. This study found that the addition of $0,5 \mathrm{~g}$ PEG to chitosan-Silica membrane resulted in a pore with a size of $0.061 \mu \mathrm{m}$, while that of $2.5 \mathrm{~g}$ produced $0.079 \mu \mathrm{m}$, and that of $5 \mathrm{~g}$ contributed to $0.087 \mu \mathrm{m}$. This shows that the produced chitosan-silica membrane is an ultrafiltration membrane with a pore range between $0.001 \mu \mathrm{m}-0.1 \mu \mathrm{m}$ [11]. From the data it can be concluded that the greater the addition of PEG, the greater the membrane pores produced. [4] have carried out the same research regarding the preparation, characterization and performance of ultrafiltration membranes with polymer (additives). The study concludes the more addition of PEG bring about larger pore size which PEG is more a pore-forming agent than a pore reducing agent.

\subsection{The Effect of PEG and PVA Composition on the Mechanical Properties of Membranes}

The characterization of mechanical properties is necessary to identify the strength of the membrane against any materials that potentially damage it. The denser the structure of the membrane means closer distance between the molecules in the membrane (the membrane has a good tensile strength). Membrane strength test was carried out at room temperature by using an Autograph that would produce Load, the tensile strength of the membrane at the time of breaking and Stroke, the strain strength at the time of breaking. The results of test to investigate the mechanical properties of the membrane are tensile strength, elongation and modulus young as outlined in Table 1 .

Table 1 Tensile Strength of Membranes in Various Compositions

\begin{tabular}{cccc}
\hline Membrane & $\begin{array}{c}\text { Tensile Strength } \\
(\mathrm{Mpa})\end{array}$ & $\begin{array}{c}\text { Elongation } \\
(\%)\end{array}$ & $\begin{array}{c}\text { Modulus Young } \\
(\mathrm{MPa})\end{array}$ \\
\hline PEG 0.5 g & 19,14 & 64,77 & 29,55 \\
PEG 2.5 g & 9.62 & 91.81 & 10,48 \\
PEG 5.0 g & 5.56 & 93.64 & 5,93 \\
PVA 1 g & 7.52 & 8,025 & 0,780 \\
PVA 2 g & 8.46 & 9,645 & 1,055 \\
PVA 3 g & 13,70 & 3,750 & 3,653 \\
\hline
\end{tabular}


Table 1 indicates that the value of modulus young decreases with the increase in the amount of PEG polymers. The value of modulus young was obtained from a comparison between the value of the tensile strength against that of elongation [13]. The value of modulus young obtained in this study is directly proportional to that of tensile strength and inversely proportional to that of elongation. Table 1 shows that the membrane with $0.5 \mathrm{~g}$ mass of PEG has a greater tensile strength value of 19.14 $\mathrm{MPa}$, elongation $64.77 \%$ and young modulus $29.55 \mathrm{MPa}$, and $3 \mathrm{~g}$ mass of Poly Vinyl Alcohol (PVA) has a greater tensile strength value of $13.7 \mathrm{MPa}$, which accords with the nature of PVA that has good elasticity and chemical stability [14]. The higher the composition of PVA in a dope solution, the smaller the pore diameter formed on the membrane due to its dense structure and the closer the distance between molecules in the membrane, making a good tensile strength $[6,15]$.

\subsection{FTIR Analysis}

The analysis of chitosan-silica membrane with FTIR aims to determine whether any solvents or additives are bound or trapped in the membrane. Data in Figure 3 demonstrate the presence of new uptake in chitosan-silica membranes that appears at wavelengths of 993.38; 979,88; $995.31 \mathrm{~cm}^{-1}$. The uptake in the form of bending at a wavelength of $900-1000 \mathrm{~cm}^{-1}$ indicates symmetrical stretching vibration from -Si-OH [16]. Data also show that uptake also appears at wavelengths of 2870.2 and 2876.95 $\mathrm{cm}^{-1}$ that indicates $\mathrm{CH}$ stretches. The wavelength of $1596.16 \mathrm{~cm}^{-1}$ is a stretch of the -NH3+ group identifying the possibility of silica bound to this amide group and the coagulation process [17].
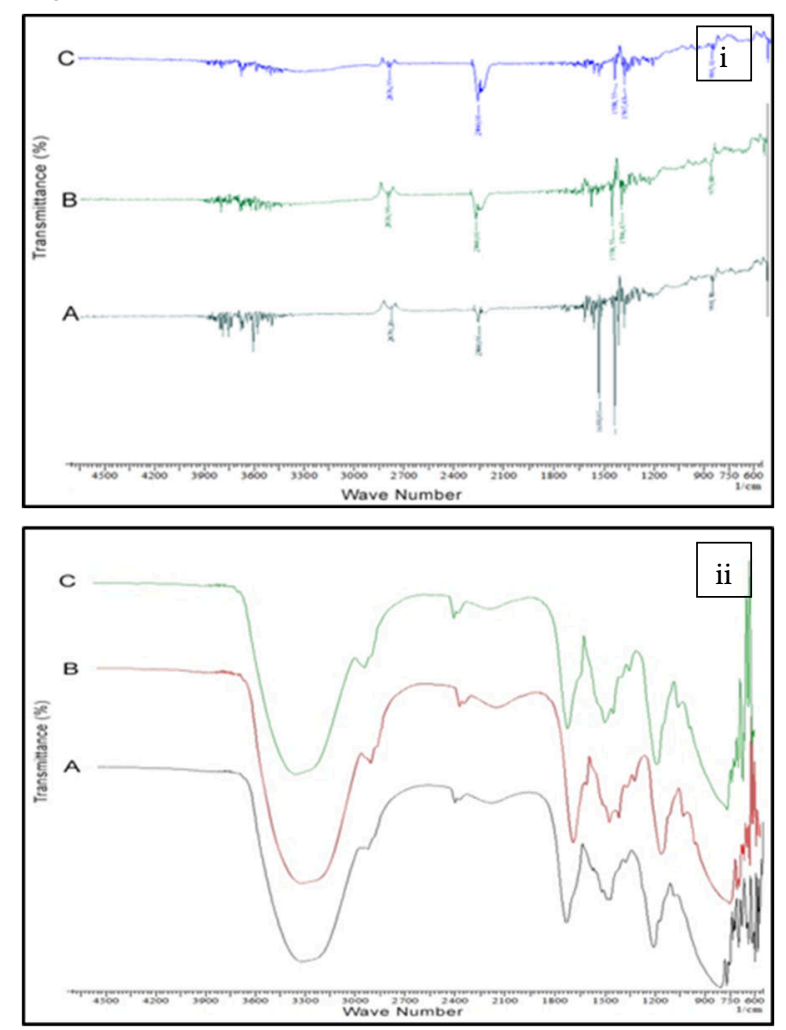

Fig. 3. FTIR Analysis of Chitosan-Silica Membrane (i) PEG Composition (ii) PVA Composition
A width uptake in the area of $1000-1250 \mathrm{~cm}^{-1}$ is the one identified from stretching symmetry -Si-O vibrations of -Si-O-Si. A new uptake appears at a wavelength of 945.16 $\mathrm{cm}^{-1}$. The uptake in the form of bending at a wavelength of $900-1000 \mathrm{~cm}^{-1}$ indicates the symmetrical stretching vibration of $-\mathrm{Si}-\mathrm{OH}$, and the uptake at wavelength $637.50 ; 638.47 \mathrm{~cm}$ ${ }^{-1}$ identifies the symmetrical stretching vibration of $-\mathrm{Si}-\mathrm{O}$ from -Si-O-C. From -Si-O-C it uptake, it is clear that identified that the added silica has interacted with chitosan. The -Si-OH stretches indicate the presence of a hydrogen bond between silanol group from the silica network and an amide or oxygroup group in chitosan [16].

The wave number $1596.16 \mathrm{~cm}^{-1}$ is a stretch of the $-\mathrm{NH}_{3}{ }^{+}$group that identifies the possibility of silica bound to the amide group and the coagulation process. The interaction between silica and chitosan opens the cavity that the membrane made from the synthesis process ultimately has a pore. The pores formed in this membrane can be used as a medium to separate two or more mixed molecules [17].

\subsection{The Effect of PEG and PVA Composition on Membrane Fluxes}

Flux is the volume of permeate passing through one unit of the surface of a membrane at a given time with the presence of a force in the form of pressure. The selectivity of the membrane is expressed in the coefficient of rejection, a measure of the ability of the membrane to hold or pass a particular species [11]. In determining the most effective membrane, the hotels wastewater pretreated using a coagulation-flocculation process was tested with the permeate analysis and initial levels of BOD, COD, TSS being carried out first. Figures 4 and 5 clearly show the results of ultrafiltration membrane process at 1 bar pressure with different variations (PEG 0.5, 2.5 and $5 \mathrm{~g}$ and PVA 1, 2, $3 \mathrm{~g})$. 1 bar was the optimum pressure on the hotel wastewater treatment.

Figure 4 illustrates that the composition of PEG was directly proportional to flux. The greater the PEG composition, the greater the flux produced. This was in accordance with the structure of the membrane that the higher the composition of the additives used, the greater the pore diameter formed on the membrane. [18] suggest that the flux value was determined by the concentration of materials composing the membrane the higher the concentration, the more solid the membrane produced, thus the greater flux value. This result was supported by [3] who conducted a study on the effect of additives on the manufacture of polysulfone-based ultrafiltration membranes for peat water purification.

Results obtained that increasing PEG composition aligns with raising value of the resulting flux, which means that the addition of hydrophilic PEG increases membrane hydrophilicity. Hydrophilic membranes tend to allow fluids to enter the pores faster when compared to hydrophobic membranes. This is what causes water to diffuse faster from one side of the membrane to the permeate side, raising the rate at which the flux flows.

In Figure 4, it is visible that the PVA-1 membrane has the greatest flux value compared to PVA-2 and PVA-3, which is made possible due to the addition of more silica 
than the amount of PVA, thereby forming a membrane structure with a gap. The membrane gap allows permeate to pass through the membrane quickly, and the speed at which the permeate passes increases the permeability value of the membrane. Nonetheless, if the value exceeds $75 \mathrm{~L} / \mathrm{m}^{2} . h$, the membrane is not fit to be used as a medium for filtration [11] since membranes with too large permeability values cannot resist unwanted species. In addition, the flux value is comparable to the permeability value of a membrane, thus PVA-1 membrane has the highest permeability value compared to the others. The flux value in this study was still below $75 \mathrm{~L} / \mathrm{m}^{2} . \mathrm{h}$, this shows that the chitosan-silica membrane was able to withstand unwanted species. The addition of inorganic material in chitosan membranes can increase the membrane permeability in the rejection coefficient value, which is a measure of the membrane's ability to hold or pass a particular species [11].

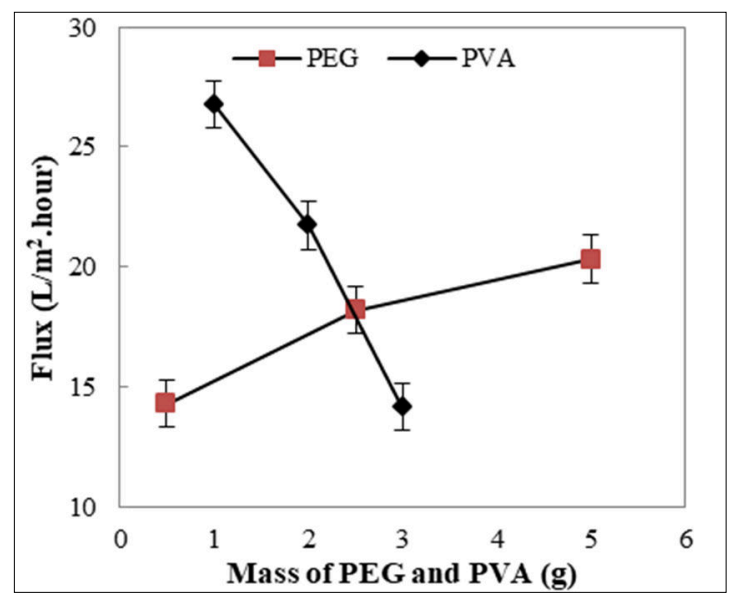

Fig. 4. The Effect of PEG and PVA Composition on Flux with Hotels Wastewater

\subsection{The Effect of PEG and PVA Composition on Membrane Rejection}

Membrane selectivity is expressed in the coefficient of rejection, a measure of the membrane ability to hold or pass a particular species [11]. Figures 5 and 6 display the results of the ultrafiltration process test at 1 bar pressure with different variations of PEG and PVA composition. 1 bar was the optimum pressure on the hotel wastewater treatment.

From Figure 6, one can see that the greater the PEG composition, the smaller the rejection value. In Figure 6, it can be seen that the operation with a $0.5 \mathrm{~g}$ PEG membrane resulted in a BOD rejection rate of $57.36 \%$, a COD of $55.79 \%$ and a TSS of $55.08 \%$. Meanwhile, the operation with $2.5 \mathrm{~g}$ PEG membrane produced a BOD rejection rate of $50.76 \%$, a COD of $46.09 \%$ and a TSS of $48 \%$, while that of 5 $\mathrm{g}$ PEG membrane generated a BOD rejection rate of $28.43 \%$, a COD of $34.12 \%$ and a TSS of $35.38 \%$.

In the operation with hotels wastewater as feed, the membrane with $5 \mathrm{~g}$ PEG composition was found to have the highest flux value in comparison to other membrane, where ini membranes with PEG $5 \mathrm{~g}$ composition, the rate of rejection that was produced against the $\mathrm{BOD}, \mathrm{COD}$ and TSS removal of hotel wastewater was significantly lower compared to that of other membrane compositions. However, the membrane operation with the composition of $0.5 \mathrm{~g}$ PEG has the highest rejection rate and the lowest flux value. Thus, the best membrane obtained from this study is that with $0.5 \mathrm{~g}$ of PEG composition, the determination of which is based on the membrane's capacity in removing the $\mathrm{BOD}, \mathrm{COD}$, and TSS parameter of larger hotel wastewater. Can be observed from Figure 7 is that the greater the PVA composition, the bigger the rate of rejection produced. Data from the figure show that the operation with $1 \mathrm{~g}$ of PVA membrane resulted in a COD of $75.39 \%$, a TSS of $57.65 \%$ and a BOD of $73.89 \%$. With $2 \mathrm{~g}$ of PVA membrane, the experiment produced a COD of $76.05 \%$, a TSS of $61.57 \%$ and a BOD of $74.27 \%$, and that of $3 \mathrm{~g}$ of PVA membrane yieled a COD of $76.72 \%$, a TSS of $65.50 \%$ and a BOD of $74.64 \%$.

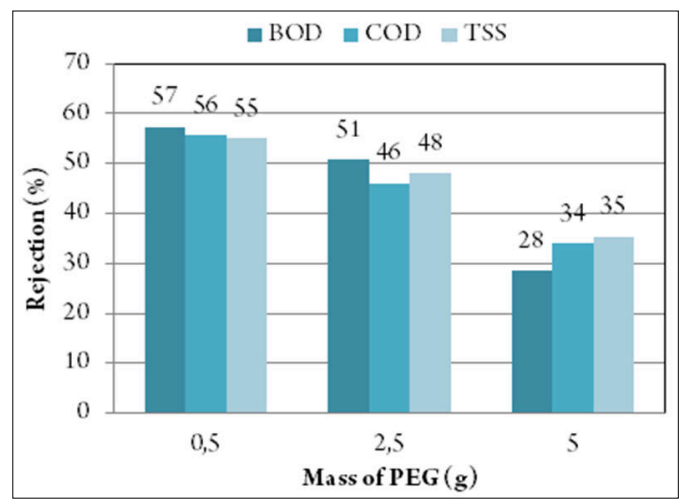

Fig. 5. The Effect of PEG Composition on Rejection with Hotels Wastewater

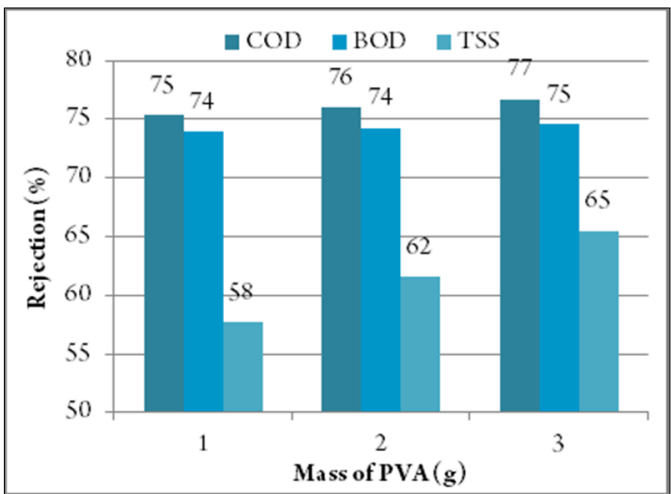

Fig. 6. The Effect of PVA Composition on Rejection with Hotels Wastewater

In the operation of membranes using hotels wastewater, the membrane with $1 \mathrm{~g}$ PVA was seen to have the highest flux value relatie to the other membranes, while the level of rejection produced against the removal of BOD, COD and TSS of hotel wastewater was considerably lower than that of other compositions. However, the operation of the $3 \mathrm{~g}$ PVA membrane resulted in the highest rejection rate and the lowest flux value. When compared to the membrane performance in terms of flux and rejection, the membrane with a composition of $2 \mathrm{~g}$ PVA is effective because it has good performance (quite large flux and a fairly good rejection rate when compared to the three other membrane compositions). From the data in Table 2, it shows that the greater the operating pressure, the percentage of BOD, COD and TSS rejection in the 3 g PVA variation was greater, whereas in the PEG variation $0.5 \mathrm{~g}$ the percentage of 
Table 2 The Percentage of Allowance or Rejection of Ultrafiltration Membrane

\begin{tabular}{lccccc}
\hline \multicolumn{1}{c}{ Assessment } & & Unit & COD & $\begin{array}{c}\text { Parameter } \\
\text { BOD }_{5}\end{array}$ & TSS \\
\hline Quality standards* & & $\mathrm{mg} / \mathrm{L}$ & 100 & 30 & 30 \\
Initial Sample & & $\mathrm{mg} / \mathrm{L}$ & 1.040 & 204 & 118 \\
After the Coagulation-Flocculation Process & & $\mathrm{mg} / \mathrm{L}$ & 304 & 98.5 & 65 \\
& 1 bar & $\%$ & 75.39 & 73.89 & 57.65 \\
Membane Rejection (3 g of PVA) & 2 bar & $\%$ & 76.05 & 74.27 & 61.57 \\
& 3 bar & $\%$ & 76.72 & 74.64 & 65.50 \\
Membrane Rejection (0.5 g of PEG) & 1 bar & $\%$ & 46.09 & 50.76 & 48.00 \\
& 2 bar & $\%$ & 43.36 & 44.16 & 45.85 \\
\hline
\end{tabular}

Source: Quality standards according to the Regulation of the Minister of Environment No. 68 of 2016

rejection decreases. From the data, the results of the COD parameter allowance has met the quality standard, while the BOD and TSS has not. This is because there were still suspended solids in the hotel wastewater. Table 2 displays the percentages of rejection rates produced on ultrafiltration chitosan-silica membranes with variations of PEG, PVA and quality standards.

\section{CONCLUSIONS}

The greater the composition of PEG, the greater the pore diameter produced. Experiments demonstrated that adding $0.5,2.5$ and $5 \mathrm{~g}$ PEG yieldthe average pore size of $0.061 \mu \mathrm{m}, 0.079 \mu \mathrm{m}$ and $0.087 \mu \mathrm{m}$ respectively, and the best tensile strength is produced from the composition of $0.5 \mathrm{~g}$ PEG, which is equal to $19.4 \mathrm{MPa}$. This study also concludes that the greater the composition of Polyethylene Glycol (PEG), the greater the value of the flux produced, although the rejection value will be smaller. A total of $0.5 \mathrm{~g}$ PEG membrane is the best membrane to use since it produces the highest rejection value, with BOD rejection value of $57.36 \%$, COD $55.79 \%$, TSS $55.08 \%$, and flux value of 14.30 $\left(\mathrm{L} / \mathrm{m}^{2} \cdot \mathrm{h}\right)$.

The greater the composition of PVA, the smaller the pore diameter produced. the addition of 1,2 and $3 \mathrm{~g}$ PVA resulted in the average pore size of $0.0296 ; 0.0305$ and $0.0284 \mu \mathrm{m}$, with the best tensile strength being in the composition of $3 \mathrm{~g}$ PVA, which is equal to $13.7 \mathrm{MPa}$. Unlike the experiment with PEG, the PVA experiment concluded that the greater the composition of the PVA, the smaller the value of the flux produced, but the greater the rejection value. The membrane with a total of $3 \mathrm{~g}$ PVA produces the highest rejection, that is, BOD of $73.89 \%$, COD $75.39 \%$, TSS $57.65 \%$, and flux value of $21.73 \mathrm{~L} /\left(\mathrm{m}^{2} . \mathrm{h}\right)$.

\section{AUTHOR INFORMATION}

\section{Corresponding Author}

Email: jhonarmedi@lecturer.unri.ac.id edysaputra@unri.ac.id

\section{ORCID}

Edy Saputra : 0000-0001-6430-9072

\section{ACKNOWLEDGEMENTS}

Financial support for this study was provided by the Ministry of Research, Technology and Higher Education of Republic of Indonesia (Kemenristekdikti).

\section{REFERENCES}

[1] Arifin, M., Starred Hotel Waste Treatment (Case Study in South Jakarta). 2000.

[2] Yuan, W., et al., Sorbitol-plasticized chitosan/zeolite hybrid membrane for direct methanol fuel cell. Journal of Power Sources, 2007. 172(2): p. 604-612.

[3] $\mathrm{Wu}, \mathrm{Y} .$, et al., PVA-silica anion-exchange hybrid membranes prepared through a copolymer crosslinking agent. Journal of Membrane Science, 2010. 350(1-2): p. 322-332.

[4] Arthanareeswaran, G., D. Mohan. Dan M. Raajenthiren, Preaparatoin, Characterization and Perfomance Studies of Ultrafiltration Membranes with Polymeric Additive. Journal of Membrane Science, 2010. 350: p. 130-138.

[5] Ma, Y., F. Shi, J. Ma, M. Wu, J. Zhang dan C. Gao, Effect of PEG Additive on the Morphology and Performance of Polysulfone Ultrafiltration Membranes. Desalination, 2011. 272: p. 51-58.

[6] Hyder, M. and P. Chen, Pervaporation dehydration of ethylene glycol with chitosan-poly (vinyl alcohol) blend membranes: effect of CS-PVA blending ratios. Journal of Membrane Science, 2009. 340(1-2): p. 171180.

[7] Wahyuningsih, S., A.H. Ramelan, D.T. Wardoyo, S. Ichsan dan Y.R. Kristiawan, Influence of Polyvinyl Alcohol (PVA) Addition on Silica Membrane Performance Prepared from Rice Straw. Materials Science and Engineering, 2017.333.

[8] Cheng, Z.L., S.C. Zi, Q.L. Hai dan L.W. Hui, NaA Zeolite Membrane with High Performance Synthesized by Vapor Phase Transformation Method. Chinese Journal of Chemistry 2010. 11: p. 14301432.

[9] Baku Mutu Limbah Hotel, Peraturan Menteri Lingkungan Hidup dan Kehutanan Republik Indonesia no. 68.2016 
[10] Wu, Y., et al., Cation exchange PVA/SPPO/SiO2 membranes with double organic phases for alkali recovery. Journal of membrane science, 2012. 423: p. 383-391.

[11] Mulder, M., Basic Principles of Membrane Technology, 2nd EdKluwer Academic Publishers. Boston, MA, 1996.

[12] Liu, J., et al., Preparation and characterization of chitosan $/ \mathrm{Cu}$ (II) affinity membrane for urea adsorption. Journal of Applied Polymer Science, 2003. 90(4): p. 1108-1112.

[13] Zou, S.B., et al., Loss of elongation factor P disrupts bacterial outer membrane integrity. Journal of bacteriology, 2012. 194(2): p. 413-425.

[14] Nguyen, H.M., Preparation and Applications of CNT-PVA/Nafion for PEMFCs. 2011.

[15] Kusumawati, N. and S. Tania, Pembuatan dan uji kemampuan membran kitosan sebagai membran ultrafiltrasi untuk pemisahan zat warna Rhodamin B. Molekul, 2012. 7(1): p. 43-52.
[16] Lee, K.-M. and Y.-M. Jo, Synthesis of zeolite from waste fly ash for adsorption of $\mathrm{CO}$ 2. Journal of Material Cycles and Waste Management, 2010. 12(3): p. 212219.

[17] Lusiana, R.A., et al., Chitosan-Tripoly Phosphate (CS-TPP) Synthesis Through Cross-linking Process: the Effect of Concentration Towards Membrane Mechanical Characteristic and Urea Permeation. Oriental Journal of Chemistry, 2017. 33(6): p. 2913-2919.

[18] Al-Moudi, A.d.L., R.W, Fouling Strategist and The Cleaning System of NF Membranes and Factors affecting Cleaning Efficiency. Journal of Membranes Science, 2007. 303: p. 4-28.

This article is licensed under a Creative Commons Attriution 4.0 International License. 